\title{
Public Discourse in the Age of Microblogging:A Content Analysis of Tweets on Sina Weibo Before the Hangzhou G20 Summit
}

\begin{abstract}
Public discussion of public affairs is one of the most essential foundations for participatory democracy. The advance of information technology facilitates public discussion in cyberspace. It is now popular for people to discuss public affairs in the blogosphere. While user behaviour and information diffusion in microblogging social networks have garnered extensive academic attention, only few studies have been dedicated to investigating the contents of tweets in response to a certain event. The current study aims to fill this gap using content analysis to examine the content of tweets on Sina Weibo regarding the G20 Summit held in Hangzhou in 2016. Some observations are made from the content of Weibo tweets. For example, NGOs and private enterprises were supportive of the event. On the other hand, the general public had more concerns about liveability issues. The findings suggest that public discussion in the blogosphere over a certain issue or topic can entail behavioural and attitudinal changes which are essential for participatory democracy. The Chinese government should take advantage of microblogging to collect views from the community for more informed decision making for policy design and project implementation.
\end{abstract}

Keywords: weibo, social media, microblogging; public discourse, content analysis
Volume 2 Issue 2 - 2018

\author{
Dinghuan Yuan, Yung Yau \\ Department of Public Policy, City University of Hong Kong, \\ Hong Kong
}

Correspondence: Yung Yau, Associate Professor, Department of Public Policy, City University of Hong Kong, Hong Kong, Tel (852) 3442 8958, Fax (852) 3442 04 I3, Email y.yau@cityu.edu.hk

Received: December 13, 2017 | Published: April 24, 2018

\section{Introduction}

Public discussion of public affairs is one of the most essential foundations for participatory democracy. ${ }^{1-3}$ with the rapid development and popularity of the Internet, people have more opportunities and channels to express their views. ${ }^{4}$ The Internet contributes to the cultivation of public awareness of social problems, offers more opportunities for community involvement, and facilitates the development of the civic society. ${ }^{5,6}$ This is ascribed to the dual function of the Internet as an information provider and a sphere for political expression. ${ }^{7,8}$ The levels of public discourse on community issues and community involvement in public affairs are further enhanced with the advancement in the interactive communication mechanisms and discussion forums. ${ }^{9}$ Internet-based social media and networks like Facebook, Twitter, and YouTube have become a new orthodoxy in the field of communication, which often brings about political changes. ${ }^{10}$

While Facebook, Twitter, and YouTube are popular applications in the West, they are unavailable in mainland China. Instead, Sina Weibo, which is akin to a hybrid of Facebook and Twitter, is one of the most popular microblogging sites in the country. ${ }^{11,12}$ By the middle of 2012, the number of registered users on Sina Weibo had reached 368 million $^{13}$ and was growing at a rate of almost 10 million per month. ${ }^{14}$ As of September 2016, Sina Weibo's monthly active users reached 297 million. ${ }^{15}$ Sina Weibo, as one of important social media, plays a very important role in the information dissemination among general individuals in China. ${ }^{16}$ With the increasing popularity of Sina Weibo, citizens even address their information needs by posting the questions on the social networks platform. ${ }^{17}$ Sina Weibo is featured by brief content and real-time reaction. More specifically, the message shared by users is limited to 140 characters and hyperlinks, images, and videos can be attached to the main text as well. ${ }^{18}$ Citizens can get information, update statuses, share views, and communicate with other users, such that information is generated and propagated rapidly on Sina Weibo. ${ }^{18,19}$ The users can follow anyone they like without prior permission so that a wide range of interpersonal relationships was created. ${ }^{20}$ The spread and resonance of the views of users on this social media platform can generate tremendous power and even affect the course of some social events, ${ }^{20}$ such as the Deng Yujiao. ${ }^{21}$ The enormous number of users and their mistrust of official information sources has helped Sina Weibo become a force in Chinese politics. ${ }^{12}$

While the user behaviours and information diffusion in microblogging social networks have attracted much attention from researchers recently, ${ }^{22,23}$ only a few studies have investigated the contents of tweets in response to a certain event. The current study aims to fill this gap by using content analysis to examine the content of tweets on Sina Weibo about the run-up to the G20 Summit in Hangzhou, China, from 4 to 5 September 2016. The G20 was initiated in 1999 and now consists of 20 countries, with the aims of discussing international financial and monetary policies, the reform of international financial institutions, and world economic development before the outbreak of the global financial crisis in 2008..$^{24,25}$ From then on, the G20 became the leaders' summit ${ }^{26}$ to preserve the current global trade and investment system, ${ }^{27}$ which gains intensive attention worldwide, especially under the contemporary context of world economic recession. Thus, the news G20 Summit coming to Hangzhou had no sooner come out than it gave rise to heated and consistent discussion on Sina Weibo. Since it indicates that China has undergone a change from membership role to recast its engagement as leadership. ${ }^{28,29}$ Even if some scholars doubt the credibility of information on Sina Weibo and argue that at least one rumour is spread on it every day, ${ }^{30}$ others hold that the verification mechanism in Sina Weibo builds trust and authenticity to the source, thus stimulating people to actively participate on the platform. ${ }^{18} 2016$ presidency for 
the G20 Hangzhou Summit has a very meaningful implication for the future of China in global governance. There is a great value to exploiting the content of tweets about the factual event of the G20 Summit. This creates an opportunity for better understanding dynamic attention paid by users, what kinds of users participate in the G20 discussion and what their frequent discussion topics are, indicating the various attitudes towards this international conference.

\section{Research methodology}

Content analysis is a method of analysing written, verbal, or visual communication messages ${ }^{31}$ that may be used with either qualitative or quantitative data and in an inductive or deductive way. ${ }^{32}$ This research method has a long history, dating back to the 18th century in Scandinavia. ${ }^{33}$ Rather than being a single method, the current applications of content analysis have been classified by Hsieh and Shannon ${ }^{34}$ into three distinct approaches: conventional,

Table I Categories and subcategories of tweets directed, or summative. This study employs the summative content analysis approach, which, according to Hsieh and Shannon, ${ }^{34}$ involves counting and comparisons, usually of keywords or content, followed by the interpretation of the underlying context. Also, this research employs the inductive method for conducting the content analysis since there are few studies about the G20 Summit posted on social media platforms. Although there are no systematic rules for analysing data, the key feature of all content analysis is that a large quantity of text is classified into much smaller content categories. ${ }^{35,36}$ The research is based on a set of first-hand data crawled from Sina Weibo. It contains 1066 tweets with the keywords "G20 Summit, Hangzhou" (杭州G20 峰会) from the 17 November 2015 to 31 March 2016 on Sina Weibo. The repetitive and irrelevant topics have already been excluded. The categories and subcategories of tweets analyzed by the inductive method are listed in the (Table 1). With the help of qualitative software NVivo 11, this research codes the data in an inductive way and use the software R to visualize some outcomes.

\begin{tabular}{|c|c|c|c|c|}
\hline Categories & Subcategories & Connotation & Days & Numbers \\
\hline & Road maintenance & $\begin{array}{l}\text { The government implements the road maintenance project to improve the } \\
\text { transportation for the G20 Summit. }\end{array}$ & 21 & 27 \\
\hline & Courteous driving & $\begin{array}{l}\text { The government proposes that drivers should be courteous to demonstrate the } \\
\text { good cultural and ethical quality of Chinese. }\end{array}$ & 12 & 23 \\
\hline & New road construction & $\begin{array}{l}\text { The government implements the new road construction projects to improve the } \\
\text { transportation for the G20 Summit. }\end{array}$ & 16 & 21 \\
\hline & Courteous travelling & $\begin{array}{l}\text { The government proposes that the citizens should be courteous while travelling } \\
\text { to demonstrate the good cultural and ethical quality of Chinese. }\end{array}$ & $\mathrm{II}$ & 14 \\
\hline & $\begin{array}{l}\text { Real-name system for } \\
\text { ticket sales }\end{array}$ & $\begin{array}{l}\text { The government implements the real-name system for bus ticket sales in order } \\
\text { to improve the safety environment for the G20 Summit, since this approach can } \\
\text { prevent terrorists from entering the city. }\end{array}$ & 6 & 7 \\
\hline & Improving traffic service & $\begin{array}{l}\text { The government improves the traffic service, such as providing English translations } \\
\text { and free } \mathrm{Wi}-\mathrm{Fi} \text { on public buses, for the G20 Summit, }\end{array}$ & 4 & 6 \\
\hline \multirow[t]{7}{*}{$\begin{array}{l}\text { Transportation } \\
\text { projects }\end{array}$} & Road light installation & The government installs LED lights along the road to improve the luminance. & 4 & 4 \\
\hline & Road name & The government unifies the English translation of road names in Mandarin. & 3 & 4 \\
\hline & $\begin{array}{l}\text { Bicycle update and } \\
\text { repair skills }\end{array}$ & $\begin{array}{l}\text { The government exchanges all the old bicycles for new ones and teaches citizens } \\
\text { how to repair bicycles. }\end{array}$ & 2 & 3 \\
\hline & $\begin{array}{l}\text { Station management and } \\
\text { maintenance }\end{array}$ & $\begin{array}{l}\text { The government improves the station management levels and renovates the } \\
\text { appearance of stations. }\end{array}$ & 3 & 3 \\
\hline & Electronic bus and line & $\begin{array}{l}\text { The government provides and increases the number of electric buses and lines to } \\
\text { protect the environment. }\end{array}$ & 2 & 2 \\
\hline & $\begin{array}{l}\text { Elimination of yellow- } \\
\text { label vehicles }\end{array}$ & $\begin{array}{l}\text { The government eliminates the polluting vehicles to protect the environment for } \\
\text { the G20 Summit. }\end{array}$ & 2 & 2 \\
\hline & Video surveillance & $\begin{array}{l}\text { The government cooperates with the DAHUA company to improve video } \\
\text { surveillance and thus improve the safety environment for the G20 Summit. }\end{array}$ & I & $\mathrm{I}$ \\
\hline
\end{tabular}




\begin{tabular}{|c|c|c|c|c|}
\hline Categories & Subcategories & Connotation & Days & Numbers \\
\hline \multirow{9}{*}{$\begin{array}{l}\text { Welcome to } \\
\text { the G20 summit } \\
\text { activities }\end{array}$} & Trail walk & The citizens participate in the trail-walk activities to celebrate the G20 Summit. & II & 21 \\
\hline & Art performance & People from all walks of life celebrate the G20 Summit by hosting art performance. & 15 & 19 \\
\hline & $\begin{array}{l}\text { Learning English and } \\
\text { related knowledge }\end{array}$ & $\begin{array}{l}\text { Citizens should learn English to demonstrate the high cultural and ethical quality } \\
\text { of Chinese. }\end{array}$ & 13 & 15 \\
\hline & Logo & $\begin{array}{l}\text { The government publishes the logo of the G20 Summit and explains the meaning } \\
\text { of the symbol }\end{array}$ & 3 & 14 \\
\hline & $\begin{array}{l}\text { Cultural expression and } \\
\text { art exhibition }\end{array}$ & $\begin{array}{l}\text { Universities, citizens, and relevant government exhibit traditional Chinese culture } \\
\text { and art, such as calligraphy and relics, to celebrate the G20 Summit. }\end{array}$ & II & 12 \\
\hline & $\begin{array}{l}\text { Promotional video and } \\
\text { celebration activities }\end{array}$ & $\begin{array}{l}\text { Television and websites play the promotional video of the G20 Summit. There are } \\
\text { also some other activities, like the light show, to celebrate the G20 Summit. }\end{array}$ & 10 & 12 \\
\hline & $\begin{array}{l}\text { Overseas publicity } \\
\text { ambassador }\end{array}$ & $\begin{array}{l}\text { Establishing the overseas publicity ambassador to advocate Chinese culture and } \\
\text { the story of Hangzhou to welcome the G20 Summit. }\end{array}$ & 5 & 5 \\
\hline & Music concert & People from all walks of life celebrate the G20 Summit by hosting a music concert. & 3 & 3 \\
\hline & Services for foreigners & $\begin{array}{l}\text { Providing the services and amenities to the foreigners to improve the popularity } \\
\text { of Hangzhou. }\end{array}$ & I & I \\
\hline $\begin{array}{l}\text { Disseminate } \\
\text { the news of the } \\
\text { G20 Summit }\end{array}$ & $\begin{array}{l}\text { Disseminate the news of } \\
\text { the G20 Summit }\end{array}$ & $\begin{array}{l}\text { People from all walks of life disseminate the news of the G20 Summit to share } \\
\text { with each other. }\end{array}$ & 30 & 102 \\
\hline \multirow[t]{5}{*}{$\begin{array}{l}\text { Expectation, } \\
\text { blessing, and } \\
\text { feeling proud }\end{array}$} & $\begin{array}{l}\text { Expectation, blessing, } \\
\text { and pride }\end{array}$ & $\begin{array}{l}\text { People from all walks of life feel proud and express their expectation and blessing } \\
\text { to Hangzhou and China. }\end{array}$ & 48 & 87 \\
\hline & Traffic congestion & $\begin{array}{l}\text { Citizens start to complain about the traffic congestion caused by the } \\
\text { transportation project, resulting in some of them even doubting the ability of the } \\
\text { government to host the G20 Summit. }\end{array}$ & 22 & 29 \\
\hline & $\begin{array}{l}\text { Damage to historic } \\
\text { buildings }\end{array}$ & $\begin{array}{l}\text { Citizens complain about the government's irresponsible behaviour that damages } \\
\text { historic buildings by implementing a housing renewal project for the G20 Summit. }\end{array}$ & 2 & 16 \\
\hline & Environmental pollution & $\begin{array}{l}\text { Citizens complain about environmental pollution, such as the dust caused by the } \\
\text { construction projects for the G20 Summit. }\end{array}$ & 8 & 10 \\
\hline & Forced demolition & $\begin{array}{l}\text { Citizens complain about forced demolition of old properties for renewal of the } \\
\text { city. }\end{array}$ & 5 & 9 \\
\hline \multirow[t]{6}{*}{$\begin{array}{l}\text { Negative } \\
\text { influence }\end{array}$} & Construction noise & Citizens complain that the construction noise interrupts their sleep. & 4 & 4 \\
\hline & Rising rental rates & $\begin{array}{l}\text { Immigrants complain about the increasing rental rates due to the house } \\
\text { demolition and regulations for the G20 Summit. }\end{array}$ & 4 & 4 \\
\hline & Delayed delivery & $\begin{array}{l}\text { Citizens complain about the delayed delivery due to the delivery inspection for } \\
\text { the G20 Summit. }\end{array}$ & 2 & 2 \\
\hline & $\begin{array}{l}\text { Interruptions to the } \\
\text { water supply }\end{array}$ & $\begin{array}{l}\text { Citizens complain that the water supply interruptions caused by the construction } \\
\text { projects makes their life inconvenient. }\end{array}$ & 2 & 2 \\
\hline & Unemployment & $\begin{array}{l}\text { Immigrants complain that reducing environmental pollution causes them to lose } \\
\text { their jobs. }\end{array}$ & $\mathrm{I}$ & 1 \\
\hline & $\begin{array}{l}\text { Environment } \\
\text { beautification project }\end{array}$ & $\begin{array}{l}\text { The government implements the environment renewal project to make the city } \\
\text { look more beautiful. }\end{array}$ & 24 & 31 \\
\hline \multirow{3}{*}{$\begin{array}{l}\text { City } \\
\text { beautification } \\
\text { projects }\end{array}$} & Building renewal project & $\begin{array}{l}\text { The government implements the building renewal project to make the city look } \\
\text { more beautiful. }\end{array}$ & 21 & 24 \\
\hline & $\begin{array}{l}\text { Construction of green } \\
\text { building }\end{array}$ & $\begin{array}{l}\text { Construction of more green buildings in Hangzhou is one of the approaches to } \\
\text { demonstrate the beauty of Hangzhou. }\end{array}$ & 6 & 14 \\
\hline & $\begin{array}{l}\text { Illegal building } \\
\text { demolition }\end{array}$ & $\begin{array}{l}\text { The government implements the directive that illegal building should be } \\
\text { demolished to demonstrate the beauty of the city. }\end{array}$ & 8 & 8 \\
\hline
\end{tabular}


Table Continued

\begin{tabular}{|c|c|c|c|c|}
\hline Categories & Subcategories & Connotation & Days & Numbers \\
\hline & Courtesy and hospitality & $\begin{array}{l}\text { The government proposes that citizens should behave courteously and hospitably } \\
\text { to be good hosts. }\end{array}$ & 25 & 43 \\
\hline \multirow[t]{6}{*}{$\begin{array}{l}\text { Being a good } \\
\text { host }\end{array}$} & $\begin{array}{l}\text { Sacrifice, striving, and } \\
\text { enthusiastic spirit }\end{array}$ & $\begin{array}{l}\text { Citizens should make sacrifices and strive with an enthusiastic spirit to be good } \\
\text { hosts. }\end{array}$ & 8 & 9 \\
\hline & $\begin{array}{l}\text { Cooperation and } \\
\text { understanding }\end{array}$ & $\begin{array}{l}\text { Citizens should cooperate and understand the inconvenience that the projects for } \\
\text { the G20 Summit bring. }\end{array}$ & 5 & 5 \\
\hline & Improving air quality & $\begin{array}{l}\text { The government implements the air clearance project to eliminate pollution to } \\
\text { show the blue sky for the G20 Summit. }\end{array}$ & 14 & 16 \\
\hline & $\begin{array}{l}\text { No firecrackers and } \\
\text { fireworks }\end{array}$ & $\begin{array}{l}\text { The government does not allow citizens to set off firecrackers and fireworks } \\
\text { during festivals to improve the environment for the G20 Summit. }\end{array}$ & 9 & 13 \\
\hline & Garbage collection & $\begin{array}{l}\text { People from all walks of life collect garbage to demonstrate the clean and tidy } \\
\text { environment for the G20 Summit. }\end{array}$ & 11 & 12 \\
\hline & Water protection & $\begin{array}{l}\text { The government implements the water protection project to clean rivers and } \\
\text { lakes for the G20 Summit. }\end{array}$ & 8 & 9 \\
\hline \multirow{11}{*}{$\begin{array}{l}\text { Environmental } \\
\text { protection } \\
\text { projects }\end{array}$} & Tree planting & The government implements the tree planting projects to make Hangzhou greener. & 5 & 5 \\
\hline & $\begin{array}{l}\text { Improving environmental } \\
\text { protection awareness }\end{array}$ & $\begin{array}{l}\text { The government implements projects to improve the citizens' awareness of } \\
\text { environmental protection. }\end{array}$ & 2 & 2 \\
\hline & Industry inspection & $\begin{array}{l}\text { The government inspects industries to see whether they are saving energy and } \\
\text { reducing emissions. }\end{array}$ & 1 & $\mathrm{I}$ \\
\hline & $\begin{array}{l}\text { Special inspection on } \\
\text { garbage trucks }\end{array}$ & $\begin{array}{l}\text { The government inspects garbage trucks to check whether they meet standards, } \\
\text { so as to improve the environment. }\end{array}$ & 1 & I \\
\hline & No spitting & The government does not allow citizens to spit in public places. & I & I \\
\hline & Garbage classification & $\begin{array}{l}\text { The government proposes garbage classification activities to protect the } \\
\text { environment for the G20 Summit. }\end{array}$ & I & 1 \\
\hline & $\begin{array}{l}\text { Volunteer application, } \\
\text { selection, and training }\end{array}$ & $\begin{array}{l}\text { NGOs advocate the volunteer application, selection, and training activities for the } \\
\text { G20 Summit. }\end{array}$ & 20 & 27 \\
\hline & $\begin{array}{l}\text { Swearing to be good } \\
\text { volunteers }\end{array}$ & Volunteers swear to be good volunteers for the G20 Summit. & 8 & 8 \\
\hline & Traffic & Volunteers induce the citizens to obey the traffic regulations. & 4 & 4 \\
\hline & Courteous behaviour & Volunteers induce citizens to behave courteously. & 1 & 4 \\
\hline & $\begin{array}{l}\text { Inspection volunteer } \\
\text { team }\end{array}$ & $\begin{array}{l}\text { Establishing the inspection volunteer team that reports illegal or inappropriate } \\
\text { behaviour. }\end{array}$ & 2 & 3 \\
\hline \multirow{7}{*}{$\begin{array}{l}\text { Volunteer } \\
\text { activities }\end{array}$} & Heart-warming tea stalls & $\begin{array}{l}\text { Volunteers provide the heart-warming tea stalls to the workers of the G20 } \\
\text { Summit. }\end{array}$ & 2 & 2 \\
\hline & Cultural expression & Volunteers help to demonstrate the cultural expression of China. & 1 & I \\
\hline & $\begin{array}{l}\text { International volunteer } \\
\text { team }\end{array}$ & $\begin{array}{l}\text { Establishing international volunteer team to serve foreigners during the G20 } \\
\text { Summit. }\end{array}$ & I & I \\
\hline & Legal volunteer team & Establishing legal volunteer team to serve the G20 Summit. & 1 & I \\
\hline & Medical care & $\begin{array}{l}\text { Volunteers teach the citizens how to carry out first aid and provide medical } \\
\text { advice. }\end{array}$ & 1 & I \\
\hline & Teaching English & Volunteers teach the citizens to speak English. & I & I \\
\hline & Trail walk & Volunteers help to carry out the trail walk. & I & I \\
\hline
\end{tabular}


Table Continued

\begin{tabular}{|c|c|c|c|c|}
\hline Categories & Subcategories & Connotation & Days & Numbers \\
\hline \multirow{5}{*}{$\begin{array}{l}\text { Other } \\
\text { influences }\end{array}$} & $\begin{array}{l}\text { Vacations and free } \\
\text { resorts }\end{array}$ & $\begin{array}{l}\text { All the citizens in Hangzhou enjoy vacations and free resorts during the G20 } \\
\text { Summit in September } 2016 .\end{array}$ & 15 & 22 \\
\hline & Stock market & The G20 Summit has a positive effect on stocks related to projects in Hangzhou. & 10 & 12 \\
\hline & Education & The G20 Summit becomes a topic for teaching and testing in school. & 7 & 8 \\
\hline & Currency rate & The G20 Summit stabilizes the RMB exchange rate. & 6 & 7 \\
\hline & House prices rising & The G20 Summit causes the house prices in Hangzhou to rise. & 5 & 6 \\
\hline \multirow{12}{*}{ Public security } & Skill training & $\begin{array}{l}\text { The police force carries out the skill-training project to improve its anti-terrorist } \\
\text { abilities so as to improve the security in Hangzhou for the G20 Summit. }\end{array}$ & 4 & 12 \\
\hline & $\begin{array}{l}\text { Security work oath- } \\
\text { taking }\end{array}$ & $\begin{array}{l}\text { The police force swears to ensure the security of Hangzhou during the G20 } \\
\text { Summit in September } 2016 \text {. }\end{array}$ & 8 & 8 \\
\hline & Temporary inspection & $\begin{array}{l}\text { The police force temporarily inspects cars, buses, and baggage to ensure the safety } \\
\text { of society. }\end{array}$ & 5 & 5 \\
\hline & Facilities inspection & Inspectors inspect the facilities to ensure the safety of the G20 Summit. & 5 & 5 \\
\hline & Patrol & The police force patrols the streets to ensure the safety of society. & 4 & 4 \\
\hline & Proving security facilities & $\begin{array}{l}\text { The police force purchases a number of security facilities to improve and ensure } \\
\text { the safety of the G20 Summit. }\end{array}$ & 2 & 4 \\
\hline & No guns or drugs & $\begin{array}{l}\text { The police force makes sure that there are no illegal guns or drugs in society to } \\
\text { ensure the safety of the G20 Summit. }\end{array}$ & 3 & 3 \\
\hline & $\begin{array}{l}\text { Establishing new security } \\
\text { teams }\end{array}$ & Establishing new security teams to ensure the security for the G20 Summit. & 3 & 3 \\
\hline & $\begin{array}{l}\text { Anti-terror drill and } \\
\text { facilities }\end{array}$ & $\begin{array}{l}\text { The police force holds anti-terror drills and inspects the anti-terror facilities to } \\
\text { ensure the safety for the G20 Summit. }\end{array}$ & 2 & 2 \\
\hline & $\begin{array}{l}\text { Disease prevention and } \\
\text { control }\end{array}$ & $\begin{array}{l}\text { Health agencies carry out disease prevention and control drill to ensure the } \\
\text { security for the G20 Summit. }\end{array}$ & 2 & 2 \\
\hline & Delivery inspection & The police force inspects deliveries to ensure the safety for the G20 Summit. & I & I \\
\hline & $\begin{array}{l}\text { Previous security } \\
\text { experience }\end{array}$ & $\begin{array}{l}\text { The police force has had previous security experience in the World Internet } \\
\text { Summit in late } 2016 \text {. }\end{array}$ & I & 1 \\
\hline \multirow{5}{*}{$\begin{array}{l}\text { Negative } \\
\text { attitudes }\end{array}$} & $\begin{array}{l}\text { Face-saving projects and } \\
\text { reduction of immigrants }\end{array}$ & $\begin{array}{l}\text { Citizens express negative attitudes to most projects for the G20 Summit, as they } \\
\text { believe they are face-saving projects and meaningless, and results in immigrants } \\
\text { leaving due to the rising rents and closing of industries. }\end{array}$ & 22 & 28 \\
\hline & Restrictions & $\begin{array}{l}\text { Citizens express negative attitudes to the restrictions for the G20 Summit like } \\
\text { restrictions on dogs. }\end{array}$ & 12 & 15 \\
\hline & No vacations & $\begin{array}{l}\text { Some workers express negative attitudes to most projects for the G20 Summit, as } \\
\text { they have no vacations. }\end{array}$ & 5 & 5 \\
\hline & No confidence & $\begin{array}{l}\text { Some older citizens express negative attitudes towards the G20 Summit, as they } \\
\text { believe it is not beneficial to China and are even concerned about the attention } \\
\text { from the world. }\end{array}$ & 3 & 3 \\
\hline & Ineffective outcome & $\begin{array}{l}\text { Citizens express negative attitudes to the G20 Summit, as the previous and } \\
\text { current ineffective outcome of projects and conference. }\end{array}$ & 2 & 2 \\
\hline
\end{tabular}


Table Continued

\begin{tabular}{|c|c|c|c|c|}
\hline Categories & Subcategories & Connotation & Days & Numbers \\
\hline & $\begin{array}{l}\text { Printing and dyeing } \\
\text { industry }\end{array}$ & $\begin{array}{l}\text { The printing and dyeing industry closes for } 3 \text { months to improve the environment } \\
\text { for the G20 Summit. }\end{array}$ & 14 & 21 \\
\hline & Chemical industry & $\begin{array}{l}\text { The chemical industry closes for } 3 \text { months to improve the environment for the } \\
\text { G20 Summit. }\end{array}$ & 4 & 7 \\
\hline & Tourist industry & The G20 Summit provides a good opportunity to develop the tourist industry. & 4 & 4 \\
\hline & Textile industry & $\begin{array}{l}\text { The textile industry closes for } 3 \text { months to improve the environment for the G20 } \\
\text { Summit. }\end{array}$ & 3 & 3 \\
\hline & $\begin{array}{l}\text { Cultural and creative } \\
\text { industry }\end{array}$ & $\begin{array}{l}\text { The G20 Summit provides a good opportunity to develop the cultural and creative } \\
\text { industry. }\end{array}$ & 2 & 2 \\
\hline \multirow[t]{9}{*}{ Industry } & Exhibition industry & The G20 Summit provides a good opportunity to develop the exhibition industry. & 2 & 2 \\
\hline & Real estate industry & $\begin{array}{l}\text { The G20 Summit influences the real estate industry in two aspects: by increasing } \\
\text { house prices and by stopping construction projects for } 3 \text { months to improve the } \\
\text { environment for the G20 Summit. }\end{array}$ & 2 & 2 \\
\hline & Silk industry & The G20 Summit provides a good opportunity to develop the silk industry. & 2 & 2 \\
\hline & Electric vehicle industry & $\begin{array}{l}\text { The G20 Summit provides a good opportunity to develop the electric vehicle } \\
\text { industry. }\end{array}$ & 1 & I \\
\hline & Steel industry & $\begin{array}{l}\text { The steel industry closes for } 3 \text { months to improve the environment for the G20 } \\
\text { Summit. }\end{array}$ & I & I \\
\hline & $\begin{array}{l}\text { Plastics processing } \\
\text { industry }\end{array}$ & $\begin{array}{l}\text { The plastics processing industry closes for } 3 \text { months to improve the environment } \\
\text { for the G20 Summit. }\end{array}$ & I & I \\
\hline & $\begin{array}{l}\text { Women should wear } \\
\text { cheongsams }\end{array}$ & $\begin{array}{l}\text { One citizen suggests that women in Hangzhou should wear cheongsams during } \\
\text { the G20 Summit in } 2016 \text {, but this suggestion is opposed by a large number of } \\
\text { citizens. }\end{array}$ & 2 & 19 \\
\hline & $\begin{array}{l}\text { Vacations and car } \\
\text { restrictions }\end{array}$ & $\begin{array}{l}\text { Citizens suggest that non-essential personnel should have vacations and that cars } \\
\text { should be restricted from entering the city during the G20 Summit. }\end{array}$ & I & 5 \\
\hline & $\begin{array}{l}\text { Using perfume and } \\
\text { cologne }\end{array}$ & $\begin{array}{l}\text { One government employee suggests that Waiters should use cologne and } \\
\text { waitresses should use perfume during the G20 Summit during the G20 Summit, } \\
\text { but it is opposed by a large number of citizens as well. }\end{array}$ & 2 & 4 \\
\hline \multirow[t]{5}{*}{$\begin{array}{l}\text { Suggestions for } \\
\text { the G20 summit }\end{array}$} & Disease prevention & $\begin{array}{l}\text { One citizen suggests that the relevant institutions should prevent the contagious } \\
\text { disease occurring. }\end{array}$ & $\mathrm{I}$ & I \\
\hline & $\begin{array}{l}\text { Increasing public parking } \\
\text { places }\end{array}$ & $\begin{array}{l}\text { One citizen suggests that the government should increase the public parking } \\
\text { places. }\end{array}$ & I & I \\
\hline & $\begin{array}{l}\text { Psychiatric hospital } \\
\text { management }\end{array}$ & $\begin{array}{l}\text { One citizen suggests that the government should improve the management of } \\
\text { psychiatric hospitals so as to provide security for the G20 Summit. }\end{array}$ & I & I \\
\hline & $\begin{array}{l}\text { Making use of security } \\
\text { personnel }\end{array}$ & $\begin{array}{l}\text { One citizen suggests that the government should take advantage of security } \\
\text { personnel to increase the security for the G20 Summit. }\end{array}$ & I & I \\
\hline & $\begin{array}{l}\text { Garbage bin } \\
\text { classification }\end{array}$ & $\begin{array}{l}\text { One citizen suggests that the government should use a new kind of garbage bin } \\
\text { classification. }\end{array}$ & I & I \\
\hline $\begin{array}{l}\text { Reasons for } \\
\text { hosting the } \mathrm{G} 20 \\
\text { Summit in } \mathrm{HZ}\end{array}$ & $\begin{array}{l}\text { Reasons for hosting the } \\
\text { G20 Summit in HZ }\end{array}$ & $\begin{array}{l}\text { Sharing the reasons why the G20 Summit was being held in Hangzhou. For } \\
\text { example, it is a historic, innovative, and beautiful city. In addition, it has played an } \\
\text { important role in diplomacy in history. }\end{array}$ & 16 & 32 \\
\hline
\end{tabular}


Table Continued

\begin{tabular}{|c|c|c|c|c|}
\hline Categories & Subcategories & Connotation & Days & Numbers \\
\hline \multirow{5}{*}{ Good influence } & $\begin{array}{l}\text { Internationalization and } \\
\text { attention }\end{array}$ & $\begin{array}{l}\text { The G20 Summit makes Hangzhou become more international and get much } \\
\text { more attention from the worldwide. }\end{array}$ & 12 & 13 \\
\hline & $\begin{array}{l}\text { Infrastructure and } \\
\text { environment }\end{array}$ & $\begin{array}{l}\text { The G20 Summit improves the infrastructure and beautifies the environment in } \\
\text { Hangzhou. }\end{array}$ & 5 & 5 \\
\hline & $5 G$ network & The G20 Summit makes Hangzhou use the $5 G$ network. & I & 1 \\
\hline & $\begin{array}{l}\text { Facilities for disabled } \\
\text { people }\end{array}$ & Providing more facilities for disabled people due to the G20 Summit. & 1 & 1 \\
\hline & Building public toilets & Building more public toilets due to the G20 Summit. & I & I \\
\hline \multirow{3}{*}{$\begin{array}{l}\text { Government } \\
\text { behaviour }\end{array}$} & Anti-corruption & $\begin{array}{l}\text { The government implements the anti-corruption campaigns to fight against } \\
\text { corruptions. }\end{array}$ & 5 & 8 \\
\hline & $\begin{array}{l}\text { Highlighting the } \\
\text { importance of the G20 } \\
\text { Summit }\end{array}$ & $\begin{array}{l}\text { The government highlights the importance of the G20 Summit in the government } \\
\text { report meeting. }\end{array}$ & 5 & 5 \\
\hline & $\begin{array}{l}\text { Communist Party and } \\
\text { working class serve as } \\
\text { pioneers }\end{array}$ & $\begin{array}{l}\text { The Communist Party and working class promise to serve as pioneers to serve } \\
\text { the G20 Summit. }\end{array}$ & 4 & 4 \\
\hline \multirow{2}{*}{$\begin{array}{l}\text { Hard work and } \\
\text { sacrifice }\end{array}$} & $\begin{array}{l}\text { Self-expressed hard } \\
\text { work and sacrifice }\end{array}$ & Some workers expressed their hard work and sacrifices for the G20 Summit. & 10 & 15 \\
\hline & $\begin{array}{l}\text { Gratitude and acclaim } \\
\text { for the sacrifices of } \\
\text { people and enterprises }\end{array}$ & $\begin{array}{l}\text { Other individuals express gratitude and acclaim for the people and enterprises } \\
\text { who sacrificed. }\end{array}$ & 9 & 10 \\
\hline Social conflicts & Social conflicts & $\begin{array}{l}\text { Some social conflicts exist in society, but some individuals worry about or even } \\
\text { blame the relevant organizations as the coming G20 Summit should have an } \\
\text { harmonious atmosphere. }\end{array}$ & II & 13 \\
\hline \multirow[b]{2}{*}{ Food projects } & Food safety inspection & The government inspects the food to ensure food safety for the G20 Summit. & 6 & 6 \\
\hline & $\begin{array}{l}\text { Specialties for the G20 } \\
\text { Summit }\end{array}$ & The interested individuals discuss the specialties for the G20 Summit. & 4 & 4 \\
\hline Accidents & Accidents & Some accidents occurred during the construction for the G20 Summit. & 4 & 9 \\
\hline Neutral attitude & Neutral attitude & Citizens express a neutral attitude to the G20 Summit. & 8 & 8 \\
\hline $\begin{array}{l}\text { Water supply } \\
\text { projects }\end{array}$ & Water supply project & $\begin{array}{l}\text { The government implements the water supply project to ensure that the stability } \\
\text { of the water supply. }\end{array}$ & 4 & 4 \\
\hline $\begin{array}{l}\text { Power supply } \\
\text { projects }\end{array}$ & Power supply project & $\begin{array}{l}\text { The government implements the power supply project to ensure the power } \\
\text { supply for the G20 Summit. }\end{array}$ & 3 & 3 \\
\hline \multirow[t]{2}{*}{ Interviews } & $\begin{array}{l}\text { Attitude to and } \\
\text { suggestions for the G20 } \\
\text { summit }\end{array}$ & Interviewing citizens for attitudes to and suggestions for the G20 Summit. & 2 & 2 \\
\hline & Preparation & $\begin{array}{l}\text { Interviewing people to determine the extent of preparation that the volunteers } \\
\text { have done for the G20 Summit. }\end{array}$ & $\mathrm{I}$ & $\mathrm{I}$ \\
\hline $\begin{array}{l}\text { Project quality } \\
\text { problems }\end{array}$ & Project quality problems & $\begin{array}{l}\text { Citizens criticize some projects for the G20 Summit, saying they are conducted } \\
\text { too quickly and not enough attention is paid to the quality. }\end{array}$ & I & 2 \\
\hline $\begin{array}{l}\text { Inspection by } \\
\text { citizens }\end{array}$ & Inspection by citizens & $\begin{array}{l}\text { The government provides a platform for the citizens to report illegal or } \\
\text { inappropriate behaviour. }\end{array}$ & I & 1 \\
\hline Others & Others & $\begin{array}{l}\text { Although the tweets include the key words "G20 Summit" and "Hangzhou", it } \\
\text { is hard to determine a specific topic, as they are mainly about people's private } \\
\text { experiences. }\end{array}$ & 26 & 36 \\
\hline
\end{tabular}




\section{Content analysis of tweets on Sina Weibo}

\section{Trend of attention analysis}

After closing of the Tenth Summit held in Antalya, Turkey (15-16 November 2015), a wide variety of tweets with regard to the news of the upcoming G20 Summit in Hangzhou started to be shared and disseminated on Sina Weibo consistently. The trend of attention by day is shown in the top of Figure 1. We can see that there are three peak values appearing on the first day after the tenth Summit, 25 March and 29 March, respectively, indicating that users responded to the news extremely promptly when it came out and the enthusiastic attention to the news dropped just rapidly in the following days. The attention rose again until the end of the March, which resulted from the event of "repainting the historic building called Qiushui shanzhuang (秋水 山庄)" condemned by a number of general public users who believed that the historic building contained original cultural elements, while renovation of such buildings instead destroys these precious and irretrievable resources. Similar to the attention by day, the attention by month, as shown in the bottom of Figure 1, from November gradually decreased to its lowest point in January, after which it rose rapidly to its peak in March. Since the tweets began in the middle of November, this explains to some extent the reason why the total number of tweets in the entire month of March is higher than in half of November (Figure 1).

\section{User-type analysis}

This study classifies the user type into the following six categories according to their identity: general public, enterprises, others, media, NGOs, and government. The specific number and their trend are shown in Figure 2. We can see that the main user type is the general public $(55.5 \%)$, which is followed by the government $(15.9 \%)$. The percentage of media users $(12.7 \%)$ is nearly twice than that of NGOs $(6.8 \%)$, while enterprises and others have a similar percentage $(4.3 \%$ and $4.8 \%$, respectively) (Figure 2). After the media and government user types published the news of the G20 Summit coming to Hangzhou, the general public responded to the news rather actively and promptly, suggesting the high enthusiasm for and expectations of general netizens towards the summit. Some citizens felt proud that Hangzhou would have such a precious opportunity to hold this international summit and expressed good wishes and congratulations for this activity. Some NGOs, including volunteer organizations and university institutes, very actively shared information regarding the volunteer application process, their selection, and training programmes.

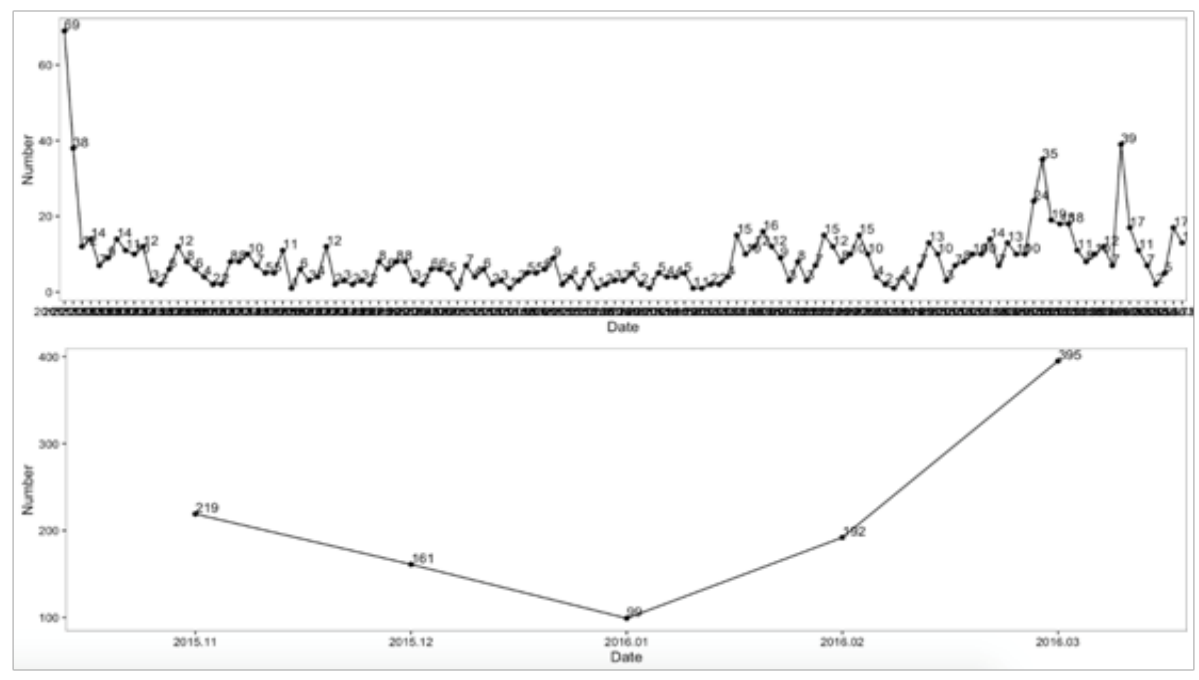

Figure I Changes in the number of tweets of the G20 summit (top panel: daily basis, bottom panel: monthly basis).

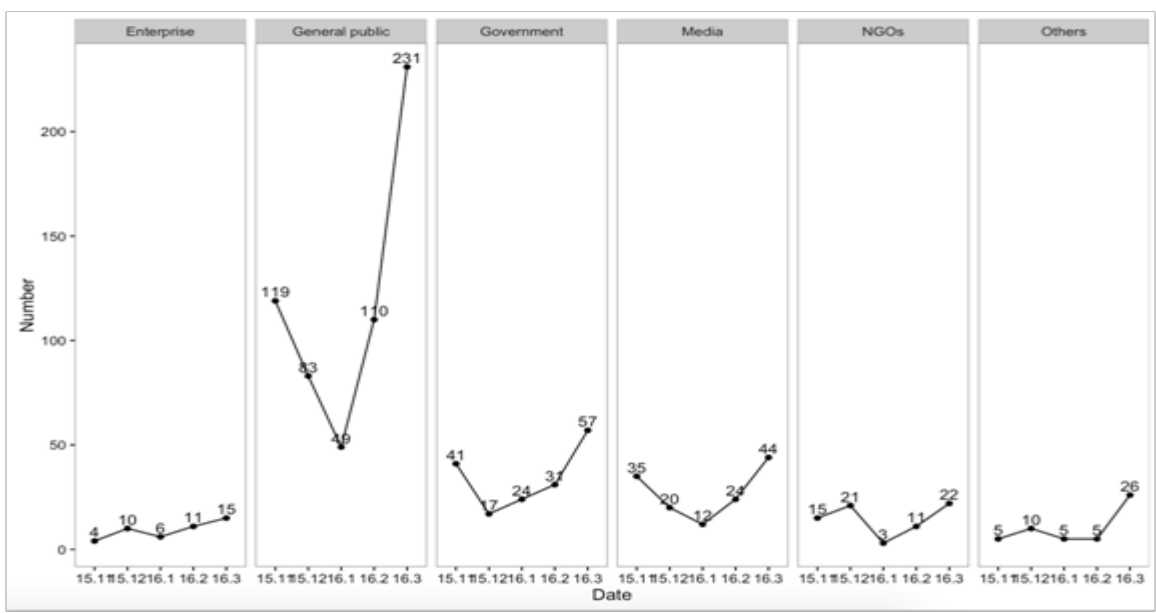

Figure 2 Longitudinal changes in number of tweets of the $\mathrm{G} 20$ summit by user type. 
This online sharing and discussion of the news encouraged many people, especially university students, to participate in the programmes. Enterprises that participated in the G20 Summit project spread the news of real-time progress of the G20 project and related activities as well. It seems that workers were really proud to carry out such arduous and emergent jobs since they believed their sacrifice to be well worth the success and safety of the G20 Summit. As for the trend of attention from different user types in response to the G20 Summit, as shown in Figure 2, the shape of the graph for the general public is very similar to that of the total trend of attention by month as shown in the bottom of Figure 1. It is clear that the attention of the general public influences the overall trend. The lowest point may be explained by the coming Lunar New Year, during which all Chinese individuals were on break to celebrate the holiday, so the attention to the G20 Summit therefore gradually decreased until January. After that, with increasing projects for the G20 Summit, the attention of the general public rebounded rapidly again. As for other user types, it is interesting to see that the graphs of the attention trend for government and media are extremely similar, indicating that the government in China could easily mobilize the media to report what they want. The graph for enterprises indicates that the Lunar New Year had little impact on this group of people since some of them still had to work. It proves again that the staff of enterprises works very hard with hardly any vacations.

\section{Content analysis of tweets}

The frequency of tweeted topics with regard to the G20 Summit coming to Hangzhou is shown in Table 1. The most frequent subject is "transportation projects", indicating that the local government invested much in physical transportation construction projects, such as "road maintenance", "new road construction", and "road light installation" that most tweets mentioned. Apart from touting the modernity and magnificence of an improving transportation infrastructure that is improving, the interior spirit of the citizens and drivers who should obey the transportation rules are also promoted. For instance, "the drivers should be courteous while driving" and "citizens should be courteous while travelling" are always posted in the tweets. The second topic is the "welcome to the G20 Summit activities" such as the trail walk, art performance and exhibition, music concert, learning English and related knowledge, and sharing the G20 logo. The third topic was "disseminating the news of the G20 Summit" (such as when and where as well as the theme of the G20 Summit), but it did not contain any subjective descriptions. The fourth topic is about expressing the "expectation, blessing, and pride" about the upcoming G20 Summit in Hangzhou. The next most frequent topics, tied for fifth place, are "negative influence" and "city beautification projects". The negative influence mainly covered the following aspects: the traffic congestion due to the transportation projects, damage to the historic buildings due to the city beautification projects, environmental pollution and construction noise, forced demolition, interruptions to water supply, rising rents, and delayed delivery. The city beautification topic referred to the environment beautification projects, building renovation projects, green building construction, and illegal building demolition (Table 2). Since the content of tweets cover multiple fields and it is impossible to analyse them one by one, this study principally focuses on the top six tweet topics as shown in Figure 3. The graphs for "disseminating the news of the G20 Summit", "welcome to the G20 Summit activities", and "expectation, blessing, and pride" are similar in that they decreased in the first three months, then started to increase. On the other hand, the topics of "city beautification projects", "negative influence", and "transportation projects" show an increasing trend in general, especially after February 2016 (Figure 3).

Table 2 Distribution of tweets on sina weibo by topics

\begin{tabular}{llll}
\hline Main topic of the tweet & Mentioned by days & Total numbers & Proportion \\
\hline Transportation projects & 53 & 115 & $9.82 \%$ \\
Welcome to the G20 summit activities & 54 & 102 & $8.71 \%$ \\
Disseminating the news of the G20 Summit & 30 & 102 & $8.71 \%$ \\
Expectation, blessing, and pride & 48 & 87 & $7.43 \%$ \\
Negative influence & 37 & 77 & $6.58 \%$ \\
City beautification projects & 47 & 77 & $6.58 \%$ \\
Being a good host & 37 & 73 & $6.23 \%$ \\
Environmental protection projects & 38 & 61 & $5.21 \%$ \\
Other influences & 35 & 55 & $4.70 \%$ \\
Volunteer activities & 39 & 54 & $4.61 \%$ \\
Negative attitude & 35 & 53 & $4.53 \%$ \\
Social security & 32 & 50 & $4.27 \%$ \\
Industry & 31 & 46 & $3.93 \%$ \\
Suggestions for the G20 Summit & 9 & 33 & $2.82 \%$ \\
\hline
\end{tabular}




\begin{tabular}{llll} 
Table Continued & Mentioned by days & Total numbers & Proportion \\
\hline Main topic of the tweet & 16 & 32 & $2.73 \%$ \\
Reasons for hosting the G20 Summit in Hangzhou & 19 & 25 & $2.13 \%$ \\
Hard working and sacrifice for the G20 summit & 18 & 23 & $1.96 \%$ \\
Good influence & 13 & 17 & $1.45 \%$ \\
Government behaviour & 11 & 13 & $1.11 \%$ \\
Social conflicts & 9 & 10 & $0.85 \%$ \\
Food projects & 4 & 9 & $0.77 \%$ \\
Accidents & 8 & 8 & $0.68 \%$ \\
Neutral attitude & 4 & 4 & $0.34 \%$ \\
Water supply projects & 3 & 3 & $0.26 \%$ \\
Power supply projects & 3 & 3 & $0.26 \%$ \\
Interview & 1 & 2 & $0.17 \%$ \\
Project quality problems & 1 & 1 & $0.09 \%$ \\
Inspection by citizens & 26 & 36 & $3.07 \%$ \\
Others & & & \\
\hline
\end{tabular}

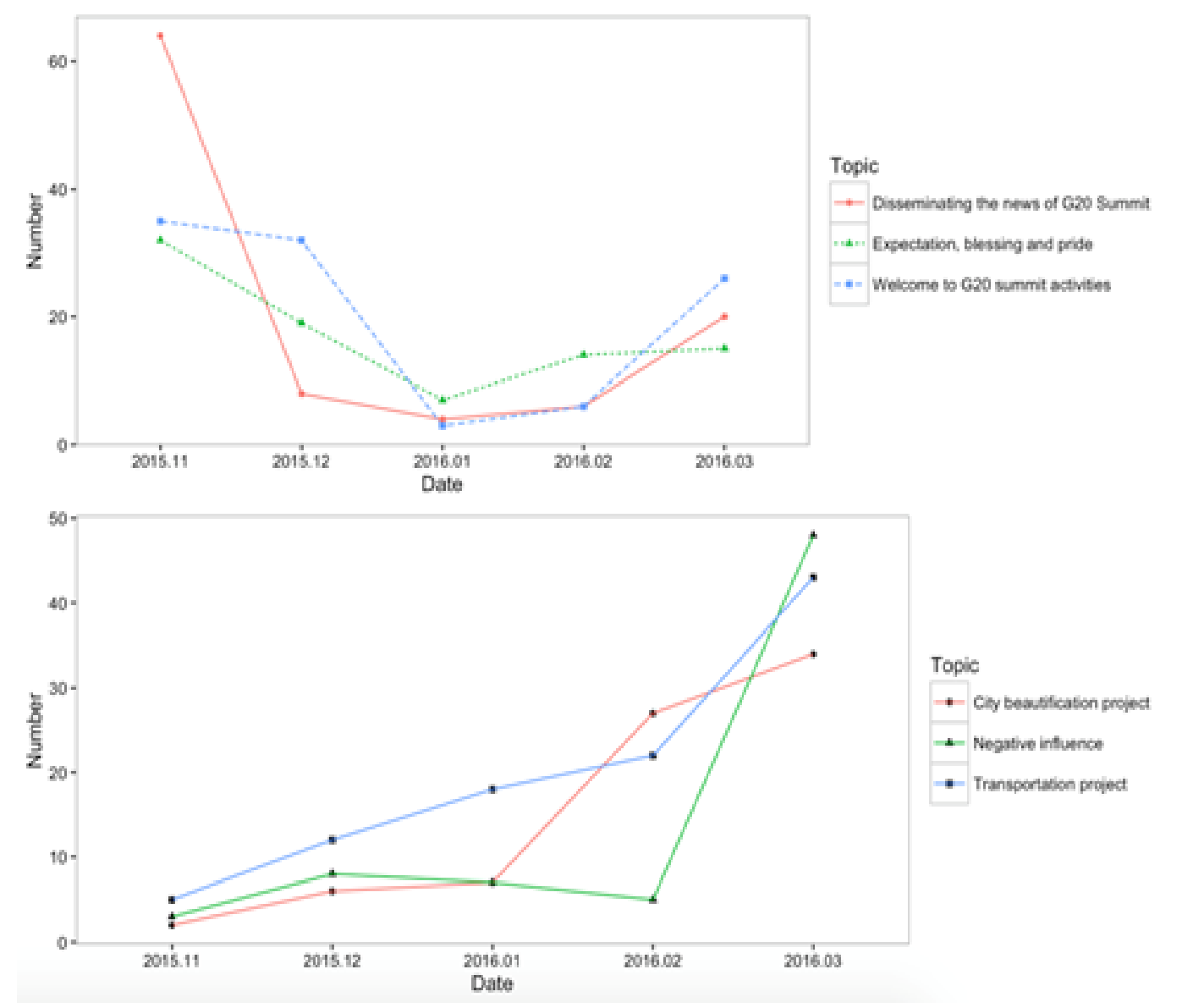

Figure 3 Numbers of tweets related to hot topics of the G20 summit. 


\section{Observations derived from the content of tweets}

\section{Government-led projects for the G20 Summit}

The top six topics posted by government users are "transportation projects"(12\%), "welcome to the G20 Summit activities"(11\%), "city beautification projects"( $11 \%)$, "security"(11\%), "being a good host" $(10 \%)$, and "environmental protection projects" $(9 \%)$. This indicates that the Chinese government highlighted this opportunity to host the G20 Summit, especially in the context that the leaders of the world's nations hoped to advance the world economy through this summit. After initiating some welcome activities such as publishing the promotional video and designing the logo for the G20 Summit, a number of projects, including "transportation" and "environmental protection", were initiated to demonstrate the good image of China to the world. The city beautification projects were subsequently initiated by policymakers. In addition to the "road maintenance" and "new road construction" projects, the government also proposed that drivers should be courteous when driving and citizens should be courteous while travelling to demonstrate the good cultural and ethical quality of Chinese. In order to reinforce this effect, "being a good host project" was launched by the government, which proposed that citizens should behave courteously and hospitably. As the environmental problem is worsening worldwide, "environmental protection projects", including improving air quality, planting trees, improving water quality, and increasing awareness of environmental protection, was also initiated by the Chinese government to demonstrate the good environment to visitors from other countries. However, after the Paris attacks in November 2015, a series of other terrorist attacks occurred in Europe, so security issues for the G20 Summit were emphasized by the Chinese government as well. For example, the police force carried out a skill-training programme to improve their anti-terrorist abilities and purchased a number of security facilities to improve and ensure the safety of the G20 Summit.

\section{Media as an important supplemental tool in disseminating the news}

As for the media users, the top five topics are "disseminating the news of the G20 Summit"(24\%), "suggestions for the G20 Summit"(11\%), "transportation projects"(11\%), "welcome to the G20 Summit activities"( $9 \%)$, "other influences" $(7 \%)$, and "being a good host" $(6 \%)$. The media, including newspapers and television, play an important role in disseminating news; it is therefore not surprising that the news of the G20 Summit coming to Hangzhou posted by the media was the most frequent topic. The "welcome to the G20 Summit activities" posted by the media were very similar to those of the government except for the topics related to publicity ambassadors

\section{Emotional change of the general public and its effects}

When the news of the G20 Summit coming to Hangzhou was posted, people from all walks of life enjoyed the news by tweeting messages "disseminating the news of the G20 Summit", posting the "welcome to the G20 Summit activities" messages, and expressing "expectation, blessing, and pride". This honeymoon period, nevertheless, did not last long. With the "transportation projects" and "city beautification projects" started, the sufferings caused by the projects for the G20 Summit occurred consistently. For example, and culture as shown in Figure 4. For example, the tweets containing the phrases "establishing the overseas publicity ambassador to advocate Chinese culture" and "the story of Hangzhou to welcome the G20 Summit" was posted by government users. The government encouraged individuals to make suggestions for the G20 Summit, and two weird suggestions given by some members of the government were posted by the media, arousing a huge attention from the public, who were strongly opposed to these stupid suggestions:

All the women in Hangzhou should wear cheongsams during the G20 Summit in 2016.

(from a delegate of the Chinese People's Political Consultative Conference)

Waiters should use cologne and waitresses should use perfume during the G20 Summit.

\section{(from a staff member of the Hangzhou city government)}

Because the media are also enterprises of a sort pursuing profit, it is understandable that they posted such news to attract public attention. Other influences of the G20 Summit, such as the "stock market", "education", "house price", and "currency rate", were also posted by the media. The topics with regard to "transportation projects" were similar to the tweets posted by the government, such as "courteous driving", "courteous travelling", and "new road construction". The topic of "being a good host" was also posted by the media, while the "negative influence" caused by the projects initiated by the government were rarely posted by the media, suggesting that the media in China are an important supplemental tool in disseminating the news that the government wants (Figure 4).

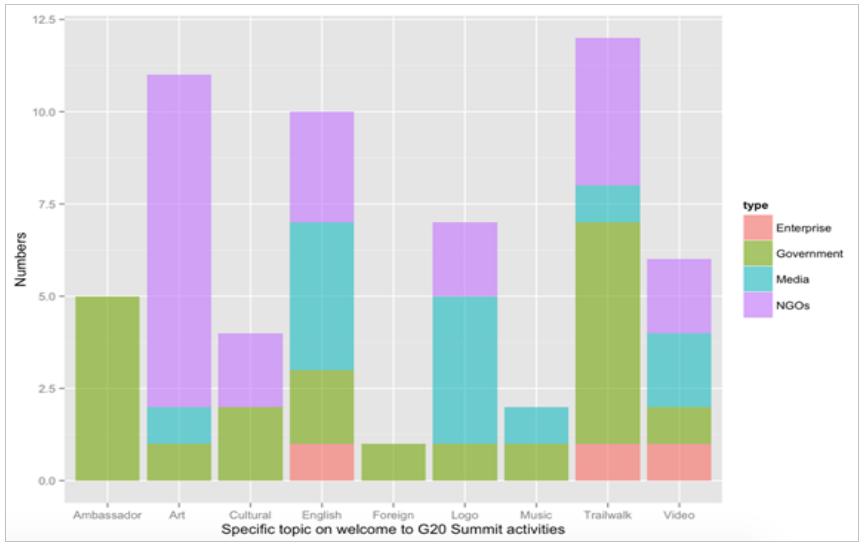

Figure 4 the comparison of different user-type on the topic of welcome to G20 summit activities.

the government emphasized the transportation projects (here mainly referring to "road maintenance" and "new road construction"), resulting in heavy "traffic congestion" in Hangzhou during the construction period, which severely affected citizens' commuting time to work and school. For example, one cyber citizen posted that "it takes one hour and twenty minutes on the road from company to home, but previously it took merely 30minutes". Another tweeted that "hosting the G20 Summit is wasting the money and boring the citizens, road maintenance and traffic congestion are all around us, it is so upsetting." 
"Construction noise" at night also affected the sleep quality of citizens. Some of them even showed negative attitudes towards the G20 Summit and blamed the government for not considering the citizens' lives. They regarded the "city beautification projects" as "facesaving projects" that were meaningless and caused inconveniences in their lives. Thus, gradually, the content of tweets started to shift from the "welcome to the G20 Summit activities", "disseminating the news of the G20 Summit", and "expectation, blessing, and pride" to the "complaints about traffic congestion", which was part of the "negative influence". The "city beautification project" initiated by the government was also described as a "face-saving project", reflecting the negative emotions towards these projects.
The spread and resonance of the negative views of the general public generated tremendous power and affected some outcomes in some cases. Take the historic building Qiushui shanzhuang as an example. The building was painted to refresh its appearance, but unfortunately it became ugly and lost its historic culture. Figure 4 shows the changes in the colour of the building. This event aroused another wave of dissatisfaction of the general public towards the inappropriate behaviour of the government. Under the pressure of public criticism, the government repainted the colour again to restore this historic building (Figure 5).
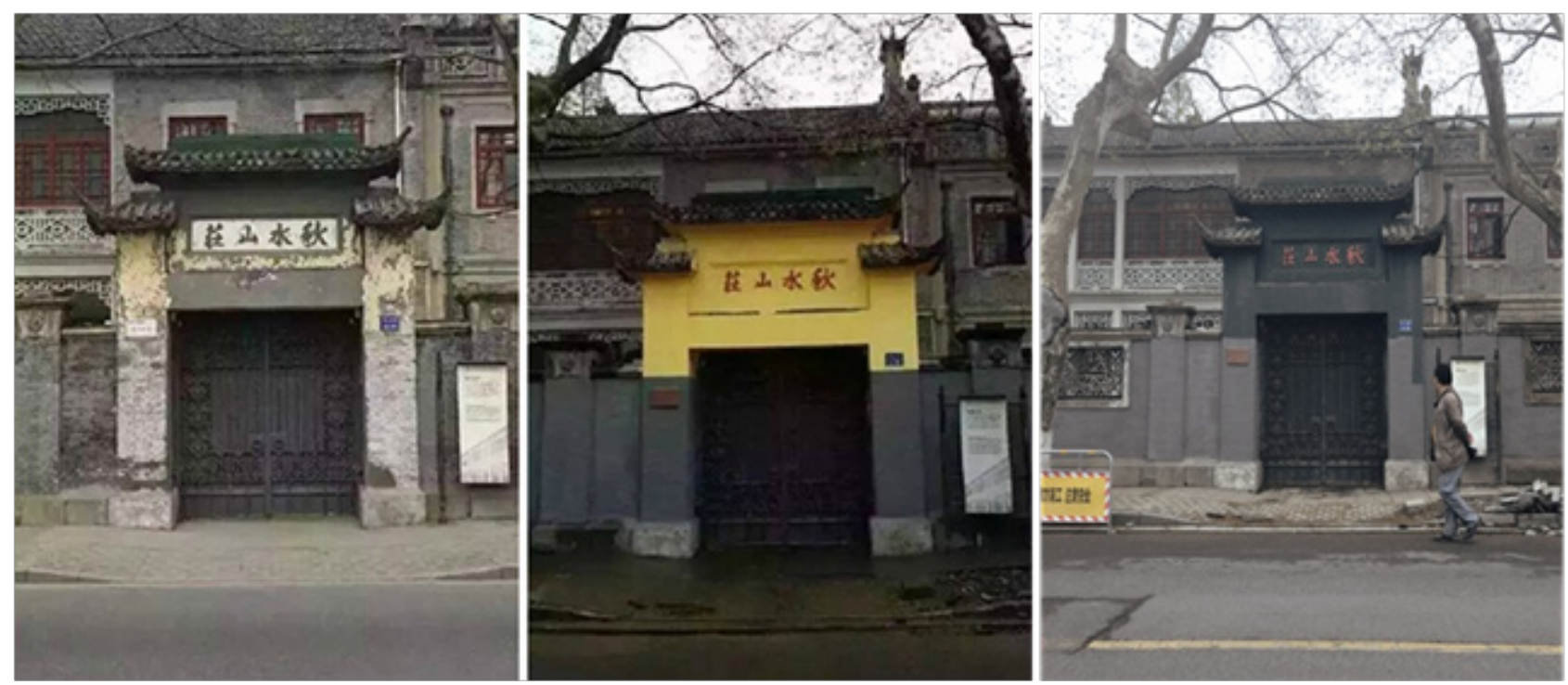

Figure 5 The colour of Qiushui shanzhuang before (left), after painting (middle), and after repainting (right).

Enterprises as important participants in the projects supporting the $\mathbf{G} 20$ Summit

The most frequent topics of enterprises, like "transportation projects"(21\%), “industry"(15\%), “environmental protection projects"(13\%), "hard work and sacrifice"(11\%) for the G20 Summit, indicate that they were rather important participants of projects for the G20 Summit, especially for the "transportation projects", such as the "new road construction", "road maintenance", and "road light installation". It is no wonder that some companies like Hangzhou Luqiao Group Limited (杭州市路桥集团有限公司) always posted the progress of the transportation project for the G20 Summit. The workers from such company work hard and sacrifice their vacations for the summit, and this was also noted on Sina Weibo to commend their behaviour. Due to the environmental protection project initiated by the government, a number of environmental protection industries, such as printing and dyeing industry, chemical industry, steel industry, and plastics processing industry, were forced to close from three to six months until the G20 Summit successfully finished in Hangzhou. In contrast, other industries, such as tourist industry, cultural and creative industry, exhibition industry, and electric vehicle industry, benefited from the G20 Summit. Unlike the general public, enterprises posted a number of tweets with regard to "being a good host", indicating that they actively responded to the government's proposals. Tweets themed as "welcome to the G20 Summit activities", such as the trail walk and promotional video, were also posted to express support for the celebration.

\section{NGOs as supporters of the government in preparation for the G20 Summit}

The majority of tweets posted from NGOs were about positive things, for instance "welcome to the G20 Summit activities"(30\%), "volunteer activities"(15\%), "disseminating the news of the G20 Summit"(9\%), "being a good host"( $8 \%$ ), and "expectation, blessing, and pride" $(5 \%)$. NGOs help the citizens to participate in some activities to welcome the G20 Summit, such as the trail-walk activities and art performances. They also teach the citizens to speak English, and deliver the promotional video for the G20 Summit that followed the government's postings. In addition, the tweets about the "volunteer application, selection, and training" were also posted by NGOs to encourage citizens and university students to participate in helping at the G20 Summit. Some tweets they posted demonstrated that they swore to be good volunteers. Other volunteer activities that the tweets mentioned were to induce citizens to behave courteously, establish inspection volunteer teams to report illegal or inappropriate behaviour, and establish international volunteer teams to serve foreigners during the G20 Summit, among others. All these activities 
indicate that NGOs responded actively to the government's appeal to be a good host. In summary, the above analysis indicates that NGOs assisted the government well in preparing some activities for hosting the G20 Summit in Hangzhou.

\section{Conclusion}

The G20 Summit has gained wide attention from almost all walks of life in China, including the government, media, general public, and NGOs. The graph showing the attention trend by month looks like a "V" shape, which can be explained by the Lunar New Year, as people in China were on break to enjoy the long holiday. There are 27 different topics with regard to the G20 Summit in total, but the top six topics do not demonstrate the same trend. Specifically, the positive and neutral topics of "disseminating the news of the G20 Summit", "welcome to the G20 Summit activities", and "expectation, blessing, and pride" show a decreasing trend for the first three months before starting to increase through March 2016. In contrast, the negative and neutral topics of "city beautification project", "negative influence", and "transportation project" all show an increasing trend in general. It can be easily understood that with government projects increasing, mainly including those of "transportation", "environmental protection", "city beautification", "being a good host", and "social security", the attention for this increased as well. This can also reflect that the government made a great effort in order to demonstrate prosperity and security to the world. The media played an important role in disseminating the news of the G20 Summit and the information, such as the "being a good host" and "courteous driving", that the government wanted.

The enterprises were important participants in projects for the G20 Summit, especially for the transportation project. The summit served as a double-edged sword to industries. While it benefited the development of some industries-such as tourist industry, cultural and creative industry, exhibition industry, and electric vehicle industryit also restricted the development of others threatening to the environment. NGOs were important supporters of the government, facilitating the organization of some volunteer activities to prepare for the G20 Summit. However, the reactions of the general public towards the G20 Summit manifest two extreme values, from "expectation, blessing, and pride" to "negative complaints". Before the government projects for the G20 Summit began, especially the "transportation project" and "city beautification project", the general public welcomed the G20 Summit in Hangzhou and expressed their expectations and blessings for it. Although the projects to prepare for the summit contributed to improving the infrastructure of Hangzhou in the long term, it caused some suffering in the short term, which is called a "short painful period" (阵痛期) by the media. Nevertheless, on a positive note, the trend of "expectation, blessing, and pride" and "welcome to the G20 Summit activities" increased during the "short painful period", as shown in Figure 3. This suggests that the general public, in effect, supported the government's decisions overall. Sina Weibo serves as a good platform to let the citizen's release their negative emotions-after all, it is anonymous.

\section{Acknowledgements}

None.

\section{Conflict of interest}

The authors declared no potential conflicts of interest with respect to the research, authorship and /or publication of this article.

\section{References}

1. Barber BR. Strong democracy: Participatory politics for a new age. Berkeley, USA: University of California Press; 1984.

2. Carey JW. The press, public opinion, and public discourse. In: Glasser TL, Salmon CT, editors. Public opinion and the communication of consent. New York: Guilford press; 1995. 373-402.

3. Huckfeldt R, Sprague J. Citizens, politics, and social communication Information and influence in an election campaign. New York: Cambridge University Press; 1995.

4. Zhou X, Chan YY, Peng ZM. Deliberativeness of Online Political Discussion. Journalism Studies. 2008;9(5):759-770.

5. Dahlberg L. Democracy via cyberspace mapping the rhetorics and practices of three prominent camps. New Media \& Society. 2001;3(2):157-177.

6. Kwak N. Talking Politics and Engaging Politics: An Examination of the Interactive Relationships Between Structural Features of Political Talk and Discussion Engagement. Communication Research. 2005;32(1):87111.

7. Dahlgren P. The Internet and the Democratization of Civic Culture. Political Communication. 2000;17(4):335-340.

8. Gil de Zúñiga H, Molyneux L, Zheng P. Social Media, Political Expression, and Political Participation: Panel Analysis of Lagged and Concurrent Relationships. Journal of Communication. 2014;64(4):612634.

9. Alexander J. Networked communities: Citizen governance in the information age. In Moore G, Whitt JA, Kleniewski N, Rabrenovic G, editors. Canada: Research in politics and society, University of Toronto press, 1999. 271-289.

10. Dann S. Twitter content classification. First Monday. University of Illinois at Chicago. 2010;15(12):1-20.

11. Gao Q, Abel F, Houben G J, et al. A comparative study of users microblogging behavior on Sina Weibo and Twitter. In International Conference on User Modeling, Adaptation, and Personalization. Canada: Berlin Heidelberg: Springer; 2012. 88-101.

12. Sullivan J. A tale of two microblogs in China. Media, Culture \& Society. 2012;34(6):773-783.

13. Bishop B. Inside Sina Weibo.USA: 2011.

14. Millward S. China's forgotten $3^{\text {rd }}$ Twitterclonehits 260millionusers. China: Routledge; 2012.

15. Corporation S. SINA reports third quarter 2016 financial results. China: Press release publishers; 2016.

16. Wang R, Rho S, Chen B, et al. Modeling of large-scale social network services based on mechanisms of information diffusion: Sina Weibo as a case study. Future Generation Computer Systems. 2017;74:291-301.

17. Liu Z, Jansen BJ. Questioner or question: Predicting the response rate in social question and answering on Sina Weibo. Information Processing \& Management. 2018;54(2):159-174.

18. Chen J, She J. An Analysis of verifications in microblogging social networks-Sina Weibo. China: ICDCSW (IEEE); 2012. 147-154.

19. Guan W, Gao H, Yang M, et al. Analyzing user behavior of the microblogging website Sina Weibo during hot social events. Physica A: Statistical Mechanics and its Applications. 2014;395:340-351. 
20. DeLuca KM, Brunner E, Sun Y. Weibo, We Chat, and the transformative events of environmental activism on China's wild public screens. International Journal of Communication. 2016;10:321-333.

21. Wikipedia. Deng Yujiao incident 2012.

22. Deng L, Jia Y, Zhou B, et al. User interest mining via tags and bidirectional interactions on Sina Weibo. World Wide Web. 2017;21(2):515-536.

23. Gan C. Gratifications for using social media: A comparative analysis of Sina Weibo and We Chat in China. Information Development. 2018;34(2):139-147.

24. G20 official website. About G20.Turkey: 2015.

25. Yu H. G20 and the Reform of Global Energy Governance. China Q of Int' l Strategic Stud. 2017;3(2):227-242.

26. Helleiner E, Pagliari S. Towards a New Bretton Woods? The First G20 Leaders Summit and the Regulation of Global Finance. New Political Economy. 2009; 14(2):275-287.

27. Akman M S, Berger A, Dadush U, et al. Key policy options for the G20 in 2017 to support an open and inclusive trade and investment system. Berlin, Germany: German Development Institute; 2017:1-4.

28. McKinney J. How stalled global reform is fueling regionalism: China's engagement with the G20. Third World Quarterly. 2017;39(4):709-726.
29. Ren X. The G20: Emerging Chinese Leadership in Global Governance? Global Policy. 2017;8(4):433-442.

30. Yang F, Liu Y, Yu X, et al. Automatic detection of rumor on Sina Weibo. China: In Proceedings of the ACM SIGKDD Workshop on Mining Data Semantics; 2012

31. Cole FL. Content analysis: process and application. Clin Nurse Spec. 1988;2(1):53-57.

32. Elo S, Kyngas $\mathrm{H}$. The qualitative content analysis process. J Adv Nurs 2008;62(1):107-115.

33. Rosengren KE. Advances in Scandinavia content analysis: An introduction. Rosengren KE, editor. Advances in content analysis. USA: Beverly Hills: Sage; 1981. 9-19.

34. Hsieh HF, Shannon SE. Three approaches to qualitative content analysis. Oual Health Res. 2005;15(9):1277-1288.

35. Burnard P. Teaching the analysis of textual data: an experiential approach. Nurse Educ Today. 1996;16(4):278-281.

36. Weber RP. Basic content analysis: Quantitative Applications in the Social Sciences (No. 49). USA, Newbury Park: Sage; 1990. 